\title{
Social Media and Learning Styles as Correlates of Senior Secondary Students' Chemistry Achievement in Abeokuta, Ogun State, Nigeria
}

\author{
Modupe M. Osokoya (Corresponding author) \\ Institute of Education, University of Ibadan \\ Nigeria
}

Email: modupeosokoya@yahoo.com

Kazeem, R

Institute of Education, University of Ibadan

Nigeria

Received: August 11, 2016 Accepted: August 29, 2016 Published: September 08, 2016

doi:10.5296/jsr.v7i2.9902 URL: http://dx.doi.org/10.5296/jsr.v7i2.9902

\begin{abstract}
Students spend most of the time they should have spent on reading on social media, meanwhile social media should be a tool for students to enhance their learning styles and improve their achievement in chemistry. Literatures revealed that both learning styles and social media affect the academic performance of students either positively or negatively, however little or no attempt has been made to investigate the effect of both on the academic achievement of students in chemistry. This study thus investigated the effect of learning styles and social media on the achievement of senior secondary school chemistry students in Abeokuta south local government of Ogun State, Nigeria. It is ex post facto research design. The population of study is all the public secondary schools students in Abeokuta South local government area of Ogun State. Random sampling was used to select five schools while forty SSIII chemistry students each were purposely selected from the schools to give a total of 200 . The students responded to three research instruments which were Chemistry Achievement Test $($ CAT) (reliability $=0.79)$, and Social Media Usage Scale (SMUS) (reliability $=0.85$ ). Five research questions were answered and data was analysed with descriptive statistics including graphical presentations. Use of Facebook (57\%) was prevalent among the students. Participative learning style $($ mean $=15.88$, mode $=17$ ) was found to be the style commonly
\end{abstract}


used by chemistry students. Both male and female students $\left(\mathrm{t}_{(198)}=1.65, \mathrm{p}>0.05\right)$ were found to be equal on the use of social media. Students usually shared more personal features than sharing ideas or knowledge. There was no significant relationship between the use of social media and students' achievement in chemistry. Science students, especially chemistry students are enjoined to devote some of the time they spent on social media for academic development rather than on social affairs mainly.

Keywords: Social media, Students' devotion, Learning styles

\section{Introduction}

Most science students who have at least credit pass in English Language and Mathematics have not been able to gain admission into the university or other higher institutions to pursue science-related courses such as medicine, pharmacy, nursing, engineering, etc. simply because they did not pass chemistry at credit level. This has been a major concern to educators and science educators in particular.

Chemistry as a subject contains abstract concepts which are seemingly difficult to grasp except students create and devote more time to study it. But it is noticed that students are not paying enough attention or creating more time to study chemistry, they are being distracted by the use of social media. Hawang, Kessler and Franceso (2004) demonstrated that students' social networking with teachers and peers boosts their knowledge acquisition and improve their academic performance. Since students also learn in different ways, there is need for the students learning styles to align with the instructors teaching style for good performance. The way students learn chemistry could also affect their performance in chemistry.

Modern technology in communication no doubt has turned the entire world into "Global village". But as it is, technology like two sides of a coin, bring with it both the negative and positive sides. It helps to be better informed, enlightened, and keeping abreast with world developments. Also, it helps students to be aware of the current developments in their field of study. Chemistry students especially should see social media as an avenue to enhancing their learning style since it provides medium of sharing new concepts, ideas or development in the field of chemistry among themselves and between them and their chemistry teachers.Alfred, Rosen and Stollak (2006) sees communication as a basic human need. Man has always found a means of meeting this need either through interpersonal or mass communication. According to a Canadian Professor of English, Marshall Mcluhan, "The world is now a global village where the whole world is now compressed into a single electronic chat room".

Katz, (2009) observes that information that usually takes many days or weeks to disseminate now takes seconds or minutes. It is now possible for people to make interpersonal communication with others to get desired information as quickly as possible from other areas of the country or from other countries with the use of social media without leaving their immediate environment.

Social networks as a global phenomenon attract extensive population from all around the 
world in different ages, cultures, education levels, etc. In addition to routinely checking e-mails, reading daily forums and newspaper or following instant message tools, people now also check their social network profiles by following others' status changes, updating their profiles or looking at others' profiles. Research has shown that many people connect to social network sites at least once a day either to check their profiles or to participate in different online activities (Joinson, 2008; Lenhart, 2009).

Most of the social network users are young individuals most of whom are tertiary and secondary school students. The relationship between the youth and their involvement in social network sites has attracted many researches that focused on young people's social network activities in relation to their privacy concerns and other forms of developments. Lenhart\& Madden, 2007; Pempek, Yermolayeva\& Calvert, 2009).

Recently, there has been considerable discussion regarding the frequent use of social media tools (e.g. Facebook, Myspace, Twitter, Whatsapp, Eskimi, 2go, Youtube, Friendster, etc.) by students most especially the secondary school students, and the possible effect of those tools on students' academic performance (Hargitai\& Hsieh, 2010). At the core of this debate is whether the growing use of social media by secondary school students actually improves or worsens a student's academic performance.

Just as the term social media has obtained a fairly broad meaning the term social networking (SNS) generally refers to internet -based locations that allow individuals and groups to interact. Usenet systems were first conceived by Tom Truscott and Jim Ellis in 1979 in which articles referred to as "news" were posted to newsgroups. Usenet had centralized server or dedicated administrator to set them apart from Bulletin Board Systems (BBSs). However group sites such as Google groups and Yahoo, use many of the conventions established by the original Usenet systems. In succession after these, many social outfits were established. There was dating sites and forums in the early 80s, six degrees in 1997 and live Journal in 1999. The early 2000s brought the emergence of Friendster (2002); Hi5 (2003); LinkedIn (2003); and MySpace (2003). Facebook and YouTube came up in 2004.

Social network sites such as MySpace, Facebook, YouTube, Badoo, Skype etc., have attracted millions of users, many of whom have integrated these sites into their daily practices. In terms of membership and daily usage, more recent estimates show Facebook as having over 750 million users worldwide; LinkedIn over 100 million members; Twitter having over 177 million tweets per day; and YouTube having over 3 billion viewers each day (Vhen, \&Bryer, 2012). Lin and Subrahmanyam (2007) found out in their studies that boys are always online more than girls because of earlier forms of technology such as video or computer games. Thelwall (2008) and Lenhart and Madden (2007) also found out that males tend to use more social media than females. However, Giles and Price (2008) reported that girls use the internet more than the boys.

Students consume a lot of time on these sites uploading or downloading, as well as watching pornography. Most students are always online every second, chatting with friends, watching online movies (pornographic films). Social site has become a habit for some students, they find it difficult to study for one hour without login to one network sites, and they can be 


\section{Macrothink}

Journal of Sociological Research

ISSN 1948-5468

2016, Vol. 7, No. 2

called "internet addicts"

In Nigeria, the statistics on internet users and population growth from the year 2000 to 2011 that was released by the Internet World Stats shows that 200,000 users out of $142,895,600$ population of people in the year 2000 has drastically increased to over 45 million users out of human population of over 155 million by the end of the year 2011. The full statistics is shown in table 1.

Table 1: Internet Usage and Population Growth in Nigeria

\begin{tabular}{|l|l|l|l|l|}
\hline YEAR & Users & Population & $\%$ Pen & Usage Source \\
\hline 2000 & 200,000 & $142,895,600$ & $0.1 \%$ & ITU \\
\hline 2006 & $5,000,000$ & $159,404,137$ & $3.1 \%$ & ITU \\
\hline 2009 & $23,982,200$ & $149,229,090$ & $16.1 \%$ & ITU \\
\hline 2011 & $45,039,711$ & $155,21,573$ & $26.5 \%$ & ITU \\
\hline
\end{tabular}

Source: http://www.internetworldstats.com/af.ng.htm

African Digital Statistics 2014 reported that Nigeria leads the way with the highest number of internet users, Facebook users and active mobile subscriptions with over 55 million users despite South Africa having higher internet, Facebook and mobile penetration. Although, it is on record that Africa continent generally, lag behind the rest of the world due to affordability access to internet on the continent. Figure 1 shows the statistics.

Figure 1: Mobile data population in Nigeria as at January 2014.

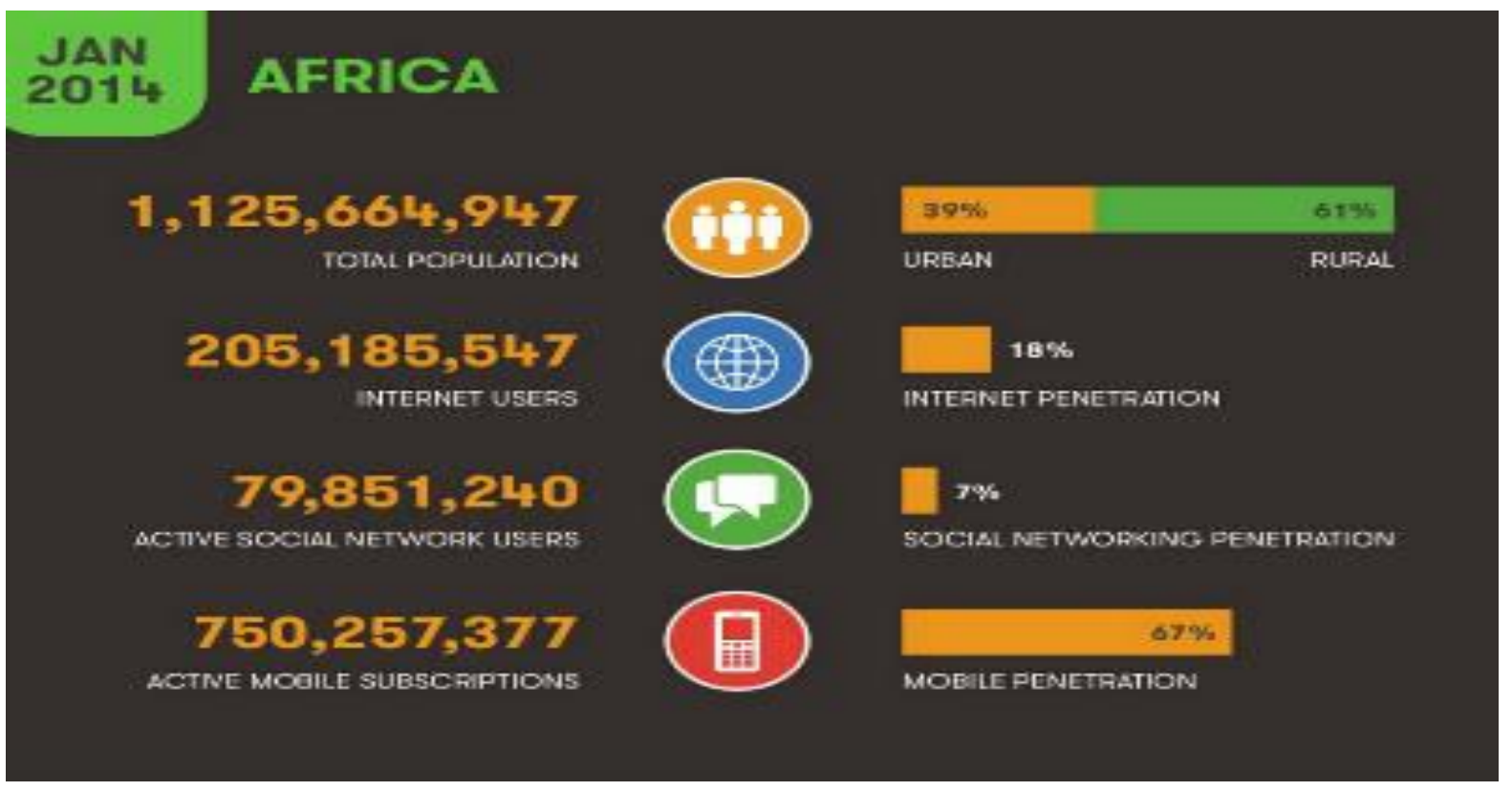


Source: http://socialmediaweek.org/lagos/2014/02/03/african-digital-statistics-2014/

According to Internet Live Stats, the internet users in Nigeria have raised to 67,101,472 as at July 2014. There is almost 1 million increase when compared with the 57.8 million reported by NCC in the year 2013. Furthermore, report gotten from Nigeria Communication Commission (NCC) as at September 2015 revealed that Nigeria Internet users have increased to 97 million. It was further analysed that MTN has 41.84 million subscribers browsing the internet on its network. Globacom has 21.89 million subscribers surfing the net on its network, Airtel had 17.73 million internet users and Etisalat had 15.59 million customers.

An effective student can actually learn better in chemistry by sharing some topics or concepts with his/her chemistry teacher or classmates. Also, students can form a forum or group on the social media where they can learn from each other, solve some problems, and share ideas with teachers. This can form a type of learning style. Learning style discusses learner's personal differences in preference to receive and process information during instruction (Johnson, 2002), it influences students innovation and technology use (Bindak, 2012). Individual learning style should be considered by teachers and other education practitioner when designing and implementing classroom activities utilizing social network sites. Preparing a learning environment that reflects students' needs is essential in improving their academic performance. Each individual has his or her own preferred way of organizing and retaining information (Chou, \& Wang, 2004) and the educational environment should be prepared according to participants' learning preferences. Creating an appropriate environment is possible only when instructional designers and instructors understand how to do so and take effective measures to shape the environment as needed (Kay et al, 2009).

Individual students differ in the way he/she learns, each student has styles or preference in the way they recognise and process information. Recognising the students' learning style may very well aid the teachers in becoming more sensitive to students' differences in the classroom, thus promoting enhancement to teaching practices that best suit the student learning styles. As stated by Cuthbert (2005), awareness of the learning styles is vital for allowing adjustment in the educators' pedagogic approaches. Garth-Johnson and Price (2000) pointed out that learner's unique learning style and academic achievements are strongly related. The researchers found out that students with collaborative learning style performed better in science subjects such as chemistry.

The learning style of the students is a very important subject in today's learner-centred education environments. According to Kolb (2000), it is a reflection of how thought is processed. Kolb developed a model of the learning cycle to illustrate how experience is translated into concepts, which in turn, are used as guide in the choice of new experiences. In Kolb's experiential learning theory, learning is a four-stage process beginning with concrete experience. These experiences form the basis for observations and reflections, which in turn lead to the formation of abstract concepts and generalization. Finally these abstract concepts or hypotheses guide in the creation of new experiences (Burd\& Buchanan, 2004). James and Gardner (1995) suggest that the way individual learners react to the overall learning environment make up the individual's learning style. Grasha and Riechmann (1974) measures 
learning styles as personal qualities which influence a student's ability to acquire information, to interact with peers and the teacher, and to participate in learning experiences. Grasha and Riechmann's model is associated with three classroom dimensions: student attitudes towards learning, their views of their teachers and peers, and their reactions to classroom procedures (Grasha, 2000).

Grasha \& Riechmann Learning Styles Inventory promotes understanding of learning in a broad context, spanning six categories: competitive, collaborative, avoidant, participant, dependent, and independent. Competitive students learn material in order to perform better than others in the class. Collaborative students feel they can learn by sharing ideas and talents. Avoidant students are not enthusiastic about learning content and attending the class. Participants are good citizens in the class. They are eager to do as much of the required and optional course requirements. Dependent learners show little intellectual curiosity and they learn only what is required. They view teacher and peers as sources of structure and support and look for authority figures. Independent learners like to think for themselves and are confident in their learning abilities. They prefer to learn the content that they feel is important. Due to distractions caused by social media and the way students learn, there is need to further research into how students' performance in chemistry have been affected by their use of social media and learning style.

Hwang, Kessler \& Francesco (2004) demonstrated that students' social networking with teachers and peers boosts their knowledge acquisition and improve their academic performance. Mobile Facebook has been investigated to be a better learning environment in higher education than commonly used learning management system in facilitating interactions, communication, collaborations and learning motivation (Chen 2014)

Mobile Facebook provides a learning environment more suitable than other learning management system that educators are already familiar with especially in facilitating opportunities for interaction, disseminating learner-created content, student engagement and immediateness (Gabarret et al, 2013). However, research has shown that online social network does not benefit all aspects of learning (Friesen \& Lowe, 2012). According to JAMB news report for 2014 UTME results, analysis of the results by JAMB Registrar, Prof. DibuOjerinde, candidates scored higher on CBT than the Paper-Pencil Test. Meanwhile, the WAEC Registrar, according to the punch newspaper of $25^{\text {th }}$ August, 2015 linked poor performance of students in Senior Secondary Certificate Examination to distraction caused by social media.

According to Maloney (2007), chemistry performance can be enhanced if teachers can guide learning by facilitating students' conversations about scientific ideas on social networking sites. He also opined that some students failed chemistry because of boring and abstract nature of chemistry class and suggested that students' performance can be improved if social media learning is introduced in teaching chemistry.

It is commonly believed that learning styles are not really concerned with "what" learners learn, but rather "how" they prefer to learn and it is also an important factor for students" academic achievement. Many researchers like Collinson (2000), Garth-Johnson and Price 
(2000), Cuthbert (2005), Johnson, (2002), are of the view that teaching styles and learning styles should be aligned in order to improve students' performances in schools. However, no particular study has linked the effect of social media and learning styles to performance of students in chemistry. According to Grasha (2000) students with participative learning style are characterized as willing to accept responsibility for self-learning and relate well with their peers. Participant learners are interested in class activities and discussion, and are eager to do as much class work as possible. They are keenly aware of and have desire to meet teacher expectations. Most of the literatures have been on general effects of social media or learning styles on students' performance. This necessitated the need for the researchers to investigate the effect of learning styles and social media on the academic achievement of students in chemistry.

Uses and gratification theory creates theoretical background for reasons why students become addicted to the use of social media. The theory explains that users of social media become addicted to it because of the gratifications they derive such as meeting new friends, chatting, watching online movies, sharing ideas with their peers, etc.

\section{The Problem}

Many factors have been highlighted in many studies to have caused poor performances of students in chemistry especially the inability to meet the required quota of 60 percent intakes in higher institution of learning for science and technology related disciplines as desired by the Nigerian Federal Government. Little attention has been paid to the use of social media and learning styles of students as they affect students' achievement in chemistry most especially in Nigeria.

Learning styles and social media usage by students have ways of playing significant roles in the performance of students in chemistry. It is not a gainsaying that social media has now become part of students' lives which they cannot do without logging on to the internet daily. Various researches have been done on the effects of social media on the academic performance of student without considering learning style as a mediating factor. This study therefore investigated the types of learning styles and social media prevalent among the students and the relationship with their performance in chemistry.

This study provides answers to the following questions:

1. What are the things chemistry students usually share on social media?

2. What is the most preferred social media among senior secondary chemistry students?

3. Is there any difference in the use of social media by male and female chemistry students?

4. What is the strength and direction of relationship between the use of social media and students' achievement in chemistry?

5. What is the pattern of learning of learning styles among senior secondary chemistry students? 


\section{Macrothink}

6. What is the strength and direction of relationship between the performances of students with different learning styles?

\section{Methodology}

This is a descriptive study. The variables studied are users of social media, learning styles and students' achievement in chemistry. The target population is all the public senior secondary school students in class 2 (SSS 2) in Abeokuta South Local Government Areas of Ogun State, Nigeria. Five Secondary Schools were randomly selected from the local government area, while forty SS2 chemistry students from the selected schools were purposively selected. A total of 200 students make up the sample for the study.

Three instruments were used for the study. These are

1. Chemistry Achievement Tests (CAT)

2. Grasha-Riechmann Student Learning Style Scale (GRSLSS)

3. Social Media Usage Scale (SMUS)

The chemistry achievement test was made up of 30 validated multiple choice test covering topics such as atoms, elements and compound; gas laws, organic chemistry and metals and non-metals. Kuder-Richardson formula 20 was used to estimate the internal consistency of CAT with a value of 0.82 .

The Grasha-Riechmann Student Learning Style Scale (GRSLSS) was adopted from Grasha-Riechmann (1999). The scale includes six styles (dependent, independent, collaborative, avoidant, competitive and participatory) each of which composed of 10 items. In the present study however, the items were reduced to 5 each with some level of re-construction. The respond format has four options, in Likert style: very true of me, true of me, almost true of me and not true of me. The final instrument was re-validated using Cronbach alpha with a reliability coefficient of 0.79 .

The social media usage scale (SMUS) was developed by the researchers. It consisted of 15-items with 4-point response like those of the learning style scale. The Cronbach alpha reliability estimate was 0.85 . Descriptive and Inferential Statistics were used to analyse the data gathered. 


\section{1) Macrothink}

\section{Results and Discussions}

\subsection{Research Question 1}

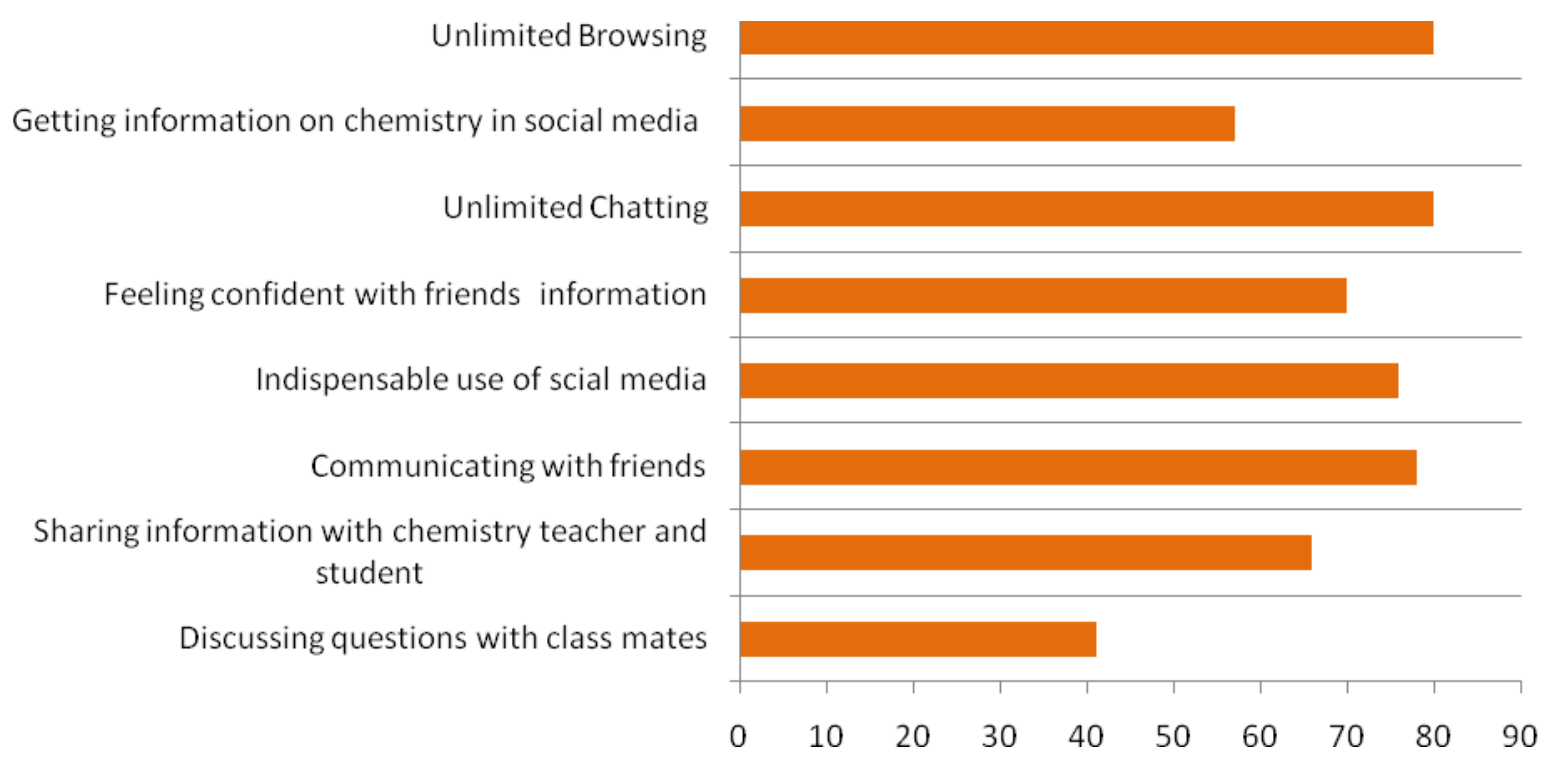

What are the things chemistry students usually share on social media?

Figure 2: Percentage Usage of Social Media

Chemistry students like other youths chat and browse (80\%) more in the internet through different social media. As reported by Johnson (2008), Lenhart (2009), Boyd (2007) and Schill (2011), young adults share more information such as pictures, birthday messages video than sharing knowledge. In this present study, only $41 \%$ of the students admitted that they try to discuss questions (on any school subject).

\subsection{Research Question 2}

What is the most preferred social media among senior secondary chemistry students?

Figure 3 shows the frequency distribution of the respondents according to the type of social media chemistry students visit 


\section{Macrothink}

Figure 3: Percentage of Respondents and Type of Social Media Prevalent among chemistry students

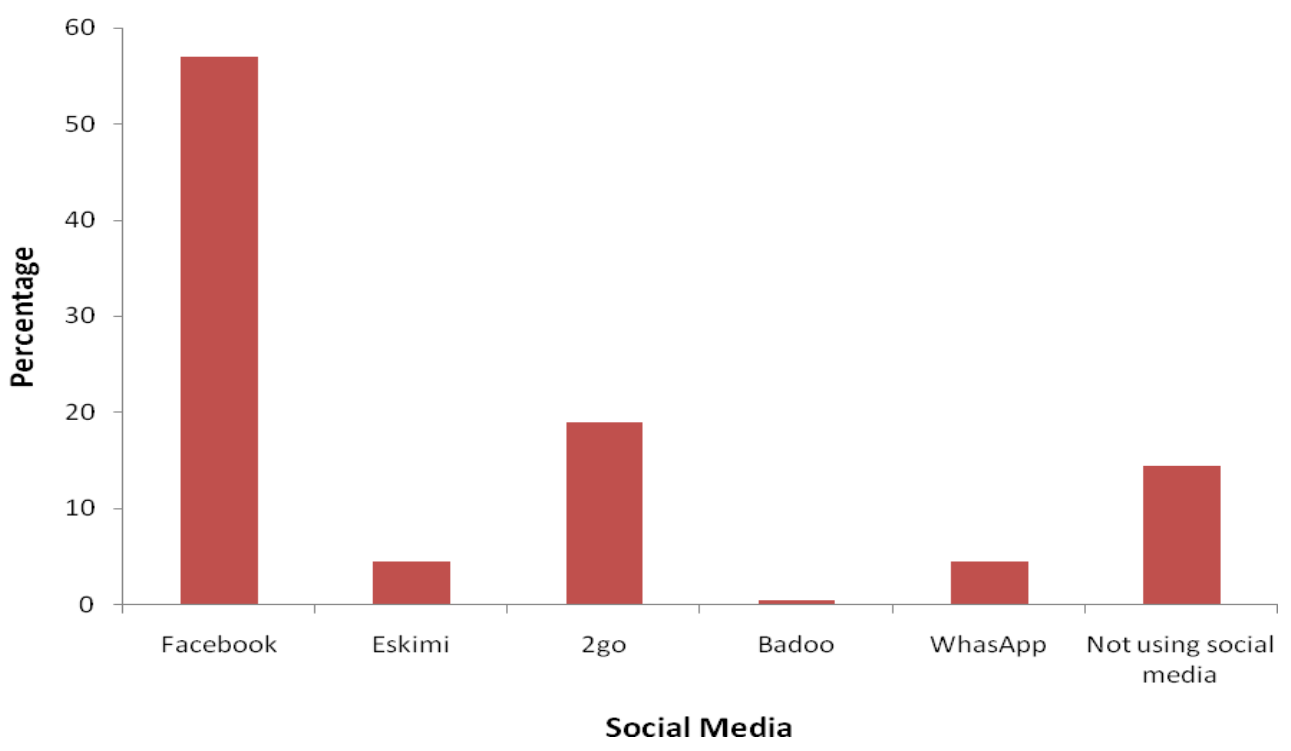

The bar chart above shows the distribution of respondents according to their most preferred social media. From the figure it is shown that 171 respondents use social media while 29 respondents do not use any of the six social media. It is also clear that out of the six types of social media, Facebook accounted for the highest percentage 57\% (114 respondents), 2go, 19\% (38 respondents), eskimi $4.5 \%$ (9 respondents), whatsapp 4.5\% (9 respondents) and badoo $0.5 \%$ (1 respondent). This means that Facebook is the most preferred social media among senior secondary students. This agrees with the observation of Chan and Bryer (2012) in which 750 million young adults worldwide admit they use Facebook, the highest among other social platforms. Olukayode and Olukunle (2014) also supported by declaring that 1000 ( $90.2 \%$ of the respondents) of the first year undergraduates from University of Ibadan use Facebook more than other social media outlets.

The opportunities provided by Facebook to the users might have accounted for the prevalence of the site among secondary school students. These opportunities are; ability of the users to create personalized profiles that includes general information such as education background, favourite interests, date of birth, and city. It also provides opportunity to post messages on friends' page, easy to find old friends, post and tag pictures and video among other things.

\subsection{Research Question 3}

Is there any difference in the use of social media by male and female chemistry students? 
Table.3: Showing difference between social media usage by male and female Chemistry students

\begin{tabular}{|l|l|l|l|l|l|l|l|}
\hline & Sex & N & Mean & SD & T & Df & Sig. \\
\hline $\begin{array}{l}\text { Social Media } \\
\text { Score }\end{array}$ & Male & 102 & 36.69 & 8.72 & 1.658 & 198 & .09 \\
\cline { 2 - 8 } & Female & 98 & 34.60 & 9.06 & & & \\
\hline
\end{tabular}

Table 3 shows that there is no significant difference in the use of social media by male and female chemistry students, $\mathrm{t}_{(198)}=1.658, \mathrm{p}>0.05$; both male and female chemistry students use social media equally. This is in agreement with the findings of Bonds-Raackes and Raackes (2008) which according to the researchers, the number of boys and girls on social media is equally divided In contrast to this result, some studies show variations in the number of males and females on social media. Lin and Subrahmanyam (2007) found out in their study that boys are always online more than girls because of earlier forms of technology such as video or computer games. Thelwall (2008) and Lenhart and Madden (2007) also found out that males tend to use more social media than females. However, Giles and Price (2008) reported that girls use the internet more than boys.

\subsection{Research Question 4}

What is the strength and direction of relationship between the use of social media and students' achievement in chemistry?

The relationship between the use of social media and students' achievement in chemistry though positive, is very low and of no statistical significance $r=0.07, p>0.05$. This means that the use of social media, did not really contribute to students achievement in chemistry. Students are not making any fruitful use of social media in their studies. This is sad, in spite of the proportion of time they devote to these social outlets in the productive age it does not reflect in their academic performances. Ahmed and Qazi (2011) also observed no significant relationship between the use of social media and students' academic performance. However, Pasek\&Hargittai (2009), Junco, Heibergert, \&Loken (2011) reported that the use of social media actually increase students' academic performance.

\subsection{Research Question 5}

What is the pattern of learning styles among the senior secondary student?

The pattern of learning styles among the students that took part in the study is shown in figure 5 . 


\section{Macrothink}

Figure 5. : Descriptive statistics of Learning Styles

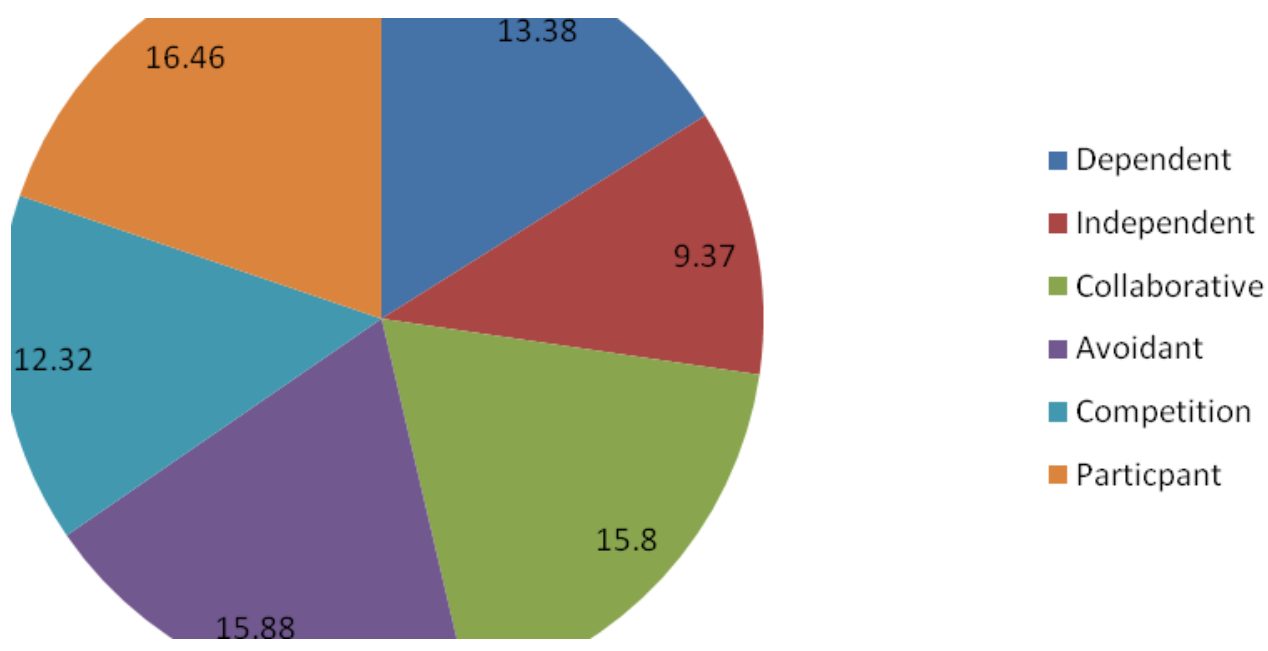

It can be observed that participant learning style has the highest mean (16.46) and highest mode $(20)$, followed by avoidant style $($ Mean $=15.88$, mode $=17)$. Collaborative $($ Mean $=$ 15.80 , mode $=16)$, dependent $($ Mean $=13.38$, mode $=14)$, competitive $($ Mean $=12.32$, mode $=11$ ), independent learning style has the lowest mean score (9.37).

This result is contrary to the findings of Mahamod, Embi and Yunus (2010), according to them art students have tendency towards collaborative and participative learning styles, while science students prefer independent learning style.

Research Question 6: What is the strength and direction of relationship between chemistry achievement of students and different learning styles?

Table 4: Correlation table of Learning Styles and Chemistry Achievement

\begin{tabular}{|l|l|l|l|l|l|l|l|l|}
\hline & & $\begin{array}{l}\text { Chemistry } \\
\text { achieveme } \\
\text { nt }\end{array}$ & $\begin{array}{l}\text { Depende } \\
\mathrm{nt}\end{array}$ & $\begin{array}{l}\text { Interde } \\
\text { pendent }\end{array}$ & $\begin{array}{l}\text { Collaborat } \\
\text { ive }\end{array}$ & $\begin{array}{l}\text { Avoida } \\
\text { nt }\end{array}$ & $\begin{array}{l}\text { Competit } \\
\text { ive }\end{array}$ & $\begin{array}{l}\text { Partici } \\
\text { pant }\end{array}$ \\
\hline $\begin{array}{l}\text { Chemistry } \\
\text { achieveme } \\
\text { nt }\end{array}$ & $\begin{array}{l}\text { Pearson } \\
\text { Correlation } \\
\text { Sig (2 tailed) } \\
\mathrm{N}\end{array}$ & 1 & .002 & $-.162^{*}$ & -.082 & -.020 & .033 & .031 \\
& 200 & 200 & 200 & 200 & 200 & 200 & .679 \\
\end{tabular}




\begin{tabular}{|c|c|c|c|c|c|c|c|c|}
\hline dependent & $\begin{array}{l}\text { Pearson } \\
\text { Correlation } \\
\text { Sig ( } 2 \text { tailed }) \\
\mathrm{N}\end{array}$ & $\begin{array}{l}.002 \\
.974 \\
200\end{array}$ & 200 & $\begin{array}{l}.062 \\
.385 \\
200\end{array}$ & $\begin{array}{l}.429 * * \\
.000 \\
200\end{array}$ & $\begin{array}{l}.370 * * \\
.000 \\
200\end{array}$ & $\begin{array}{l}.288 * * \\
.000 \\
2000\end{array}$ & $\begin{array}{l}.390 * \\
* \\
.000 \\
200\end{array}$ \\
\hline $\begin{array}{l}\text { Interdepen } \\
\text { dent }\end{array}$ & $\begin{array}{l}\text { Pearson } \\
\text { Correlation } \\
\text { Sig (2 tailed }) \\
\mathrm{N}\end{array}$ & $\begin{array}{l}1.162 * \\
.022 \\
200\end{array}$ & $\begin{array}{l}0.62 \\
.385 \\
200\end{array}$ & 1 & $\begin{array}{l}.170 * \\
.016 \\
200\end{array}$ & $\begin{array}{l}.141 * \\
.047 \\
200\end{array}$ & $\begin{array}{l}.159 * \\
.024 \\
200\end{array}$ & $\begin{array}{l}-.124 \\
.080 \\
200\end{array}$ \\
\hline $\begin{array}{l}\text { Collaborat } \\
\text { ive }\end{array}$ & $\begin{array}{l}\text { Pearson } \\
\text { Correlation } \\
\text { Sig (2 tailed) } \\
\text { N }\end{array}$ & $\begin{array}{l}-.082 \\
.249 \\
200\end{array}$ & $\begin{array}{l}.429 * * \\
.000 \\
200\end{array}$ & $\begin{array}{l}.170 * \\
.016 \\
200\end{array}$ & 200 & $\begin{array}{l}.429 * * \\
.000 \\
200\end{array}$ & $\begin{array}{l}.191^{* *} \\
.007 \\
200\end{array}$ & $\begin{array}{l}298 * * \\
000 \\
200\end{array}$ \\
\hline Avoidant & $\begin{array}{l}\text { Pearson } \\
\text { Correlation } \\
\text { Sig (2 tailed }) \\
\mathrm{N}\end{array}$ & $\begin{array}{l}-.020 \\
.781 \\
200\end{array}$ & $\begin{array}{l}.370 * * \\
.000 \\
200\end{array}$ & $\begin{array}{l}.141 * \\
.047 \\
200\end{array}$ & $\begin{array}{l}.429 * * \\
.000 \\
200\end{array}$ & 200 & $\begin{array}{l}.268 * * \\
.000 \\
200\end{array}$ & $\begin{array}{l}.469 * \\
* \\
.000 \\
200\end{array}$ \\
\hline $\begin{array}{l}\text { competitiv } \\
\text { e }\end{array}$ & $\begin{array}{l}\text { Pearson } \\
\text { Correlation } \\
\text { Sig (2 tailed) } \\
\mathrm{N}\end{array}$ & $\begin{array}{l}.033 \\
.647 \\
200\end{array}$ & $\begin{array}{l}.288 * * \\
000 \\
200\end{array}$ & $\begin{array}{l}159 * \\
.024 \\
200\end{array}$ & $\begin{array}{l}.191 * * \\
.007 \\
200\end{array}$ & $\begin{array}{l}.268 * * \\
.000 \\
200\end{array}$ & 200 & $\begin{array}{l}.335^{*} \\
* \\
.000 \\
200\end{array}$ \\
\hline Participant & $\begin{array}{l}\text { Pearson } \\
\text { Correlation } \\
\text { Sig (2 tailed }) \\
\mathrm{N}\end{array}$ & $\begin{array}{l}.031 \\
.658 \\
200\end{array}$ & $\begin{array}{l}.390 * * \\
.000 \\
200\end{array}$ & $\begin{array}{l}-.124 \\
.080 \\
200\end{array}$ & $\begin{array}{l}.298 * * \\
.000 \\
200\end{array}$ & $\begin{array}{l}.469 * * \\
.000 \\
200\end{array}$ & $\begin{array}{l}.335^{* *} \\
.000 \\
200\end{array}$ & 200 \\
\hline
\end{tabular}

- Correlation is significant at the 0.05 level (2-tailed).

Table 5 shows the relationship between learning style preferences and achievement of students in chemistry. There is negative correlation between chemistry achievement and independent style, $r=-.162, \mathrm{p}<.05$, collaborative style, $r=-.082, \mathrm{p}>.05$ and avoidant style, $\mathrm{r}$ $=-.020, \mathrm{p}>.05$. On the other hand, the result shows positive correlation between chemistry achievement and dependent style, $\mathrm{r}=.002, \mathrm{p}>.05$, competitive style, $\mathrm{r}=.033,0>.05$ and 
participant style, $r=.031, \mathrm{p}>.05$.

Based on the result, there is no statistical significant relationship between chemistry achievement and learning styles. Although there is significant relationship between chemistry achievement and independent style, the strength of the relationship is very small and negative. This result is in line with the submission of Bloomer and Hodkinson (2000) who criticized learning style research, to them students' academic performance does not depend on their learning styles. But contrary to this result, Garth-Johnson and Price (2000) pointed out that learner's unique learning style and their academic achievements are strongly related. Collinson (2000) and Snyder (2000) found out that students' academic achievement differed due to different learning styles. The results of the study conducted by Grasha and Yangarber-Hicks (2000) indicated that students who got distinctions in science courses were independent learners, but there was no relationship between competitive learning style and achievement.

\section{Conclusion}

The research has shown that Facebook is the most commonly used social networking site and participative learning style is the predominant learning style among chemistry students. There was no significant relationship between students' achievement in chemistry and learning styles, though a weak but positive relationship exist between independent learning style and achievement in chemistry. There is no remarkable relationship between use of social media and students' achievement in chemistry, even though students spend a great proportion of their time on chatting and browsing they do not use it productively to enhance their academic achievement in chemistry.

Teachers can make students more participative and independent in their learning by engaging them in social media learning since most students are on social media network. Chemistry teachers can share topics, ideas and information with students on social media. He/she may posts assignment to them on social media, and the students post back the solutions to assignment to their teacher within a stipulated time; though this will require more commitment from the teachers. School administrators should try to find ways of incorporating social media into learning and this can only be achieved if school proprietors and government create internet access in schools.

\section{References}

Ahmed, I.Q \&Qazi, F.T (2011): A Look Out For Academic Impacts Of Social Networking Sites (SNSs): A student based perspective. African Journal of Business Management

Alfred T.A., Rosen, L., \&Stollak M.J. (2006): The Media: An Introduction: ( ${ }^{\text {rd }}$ edition). England: Pearson Education Limited.

Boyd, D. \& Ellison, N. (2007): Social network Sites: Definition, History and Scholarship. Journal of Computer-mediated Communication, 13, (1) 


\section{Al Macrothink}

Journal of Sociological Research

ISSN 1948-5468

2016, Vol. 7, No. 2

Burd, B.A. and Buchnnan, L.E. (2004): Teaching the Teachers:Teaching and Learning Online Reference Services Review, 404-412.

Canales, C., Wilbanks, B., \& Yeoman, A. (2009): Facebook Usage in Relation to Personality and Academic Performance. Modern Psychological Studies, Spain

Cassidy, S. (2004): Learning Styles: An Overview of Theories, models; and Measures, Educational Psychology, 24 (4), 419-444.

Chen, Y. (2014): The Effect of Using a Facebook Group as a Learning Management System. Computers in Education Journal

Chen, B., \&Bryer, T. (2012): Investigating Instructional Strategies for Using Social Media in Formal and Informal Learning. The International Review of Research in Open and Distance Learning, 13 (1), 87-104.

Chou, H. \& Wang, T. (2000): The Influence of Learning Style and Training Method on Self-efficacy and Learning Performance. International Journal of Information Management

Collinson, E. (2000): A Survey of Elementary Students Learning Styles Preferences and Academic Success.Journal of Contemporary Education.

Cuthbert, P.F (2005):The Student Learning Process; Learning Styles or Learning Approaches? Teach Higher Education, 10 (2), 235-243.

Grant, N. (2008): On the Usage of Social Networking Software Technologies in Distance Learning Education. In K. Mcferrin et al. (Eds).Proceedings of Society for information Technology and Teacher Education International Conference 2008

Grasha, A.F. (2000): Teaching with Style: A Practical Guide to Enhancing Learning by Understanding Teaching and Learning Styles. Pittsburgh: Alliance Publishers.

Grasha, A.F. and Riechmann, S.W. (1974): A Rational Approach to Developing and Assessing the Construct Validity of a Student Learning Style Scales Instruments. The Journal of Psychology, 87, 213-233.

Giles, G and Price, R. (2008)) Adolescent Computer use: Approach, Avoidance and Parental Control. Australian journal of Psychology

Hargittai, E., \& Hsieh, Y.P (2010): Predictors and Consequences of Differentiated Practices in Social Network Sites. Information, Communication \& Society 13(4), 515-536.

Hwang, A., Kessler, E.H. \& Francesco, A.M. (2004): Student Networking Behaviour, Culture and Grade Performance: An Empirical Study and Pedagogical Recommendations. Academy of Management Learning and Education

Israel, J.A. (2005): Causes of Students' Low Enrolment in Chemistry. Journal of Empirical Research in Science and Technology Education (181)

James, W.B., and Gardner, D.L. (1995): Learning Styles: Implications for Distance Learning.New Directions for Adult and Continuing Education (67), 19-32. 


\section{Macrothink}

Journal of Sociological Research

ISSN 1948-5468

2016, Vol. 7, No. 2

Joinson. A.N (2008): 'Looking at', or 'Looking up', or 'Keeping up with' People, Motives and Uses of Facebook .Proceedings of CHI 2008. Florence, Italy.

Junco, R., Heibergrt, G., and Loken, E. (2011): The Effect of Twitter on College student Engagement and Grades. Journal of Compute Assisted Learning.

Katz, (2009): Introduction to Mass Communication: Media Literacy and Culture: $\left(2^{\text {nd }}\right.$ Edition). New York: McGraw Hill Companies.

Koca, A. (2009): Facebook 2008: Proceedings of the 2009 Twenty Anniversary Conference on Computer Supported Cooperative Work (pp. 167 - 170). New York: CAN Press.

Kolb, D.A. (2000: $\quad$ Learning Style Inventory: Technical Manual. Boston: Mcber\& Co.

Kolb, A.Y., and Kolb, D.A. (2005): $\quad$ Learning Styles and Learning Spaces: Enhancing Experiential Learning in Higher Education. Academy of Management Learning and Education.

Lenhart, A. (2009): Teens and Social Media: An Overview, 22. New York; Pew internet \& American Life Project.

Lenhart, M. (2009): Adults and Social Network Websites.Pew Internet \& American Life Project Report.

Lenhart, M. \& Madden, M. (2007): Teens, Privacy and Outline Social Networks. How Teens Manage their Online Identities and Personal Information in the Age of MySpace. Pew Internet \& American Life Project Report.

Lin, G. and Subrahmanyam, K. (2007): Adolescents and the Net: Internet Use and Well-being Journal of Adolescent Research

Pew (2009): Inforgraphics Retrieved 2013 from Pew Internet.

Stollak, MJ., Vandenberg. A., Burklund, A., and Weiss, S. (2011):Getting Social: The Impact of Social Networking Usage on Grades Among College Students. UK.

Thelwall, M. (2008): Social Networks, Gender and Friending: An Analysis of MySpace Member Profiles. Journal of the American Society for Information Science and Technology

Wang. Q., Chen W., and Liang Y. (2011): The Effects of Social Media on College Students. The Alan Shawn Feinstein Graduate School Providence: Johnson \& Wales University.

Wang, S.L. and Wu, P.Y. (2008): The Role of Feedback and Self-efficacy on Web-based Learning: The Social Cognitive Perspective.Computer and Educational Journa, Wales.

\section{Copyright Disclaimer}

Copyright for this article is retained by the author(s), with first publication rights granted to the journal. 
This is an open-access article distributed under the terms and conditions of the Creative Commons Attribution license (http://creativecommons.org/licenses/by/3.0/). 